\title{
Selective and Nonselective Stimulation of Central Cholinergic and Dopaminergic Development in vitro by Nerve Growth Factor, Basic Fibroblast Growth Factor, Epidermal Growth Factor, Insulin and the Insulin-like Growth Factors I and II
}

\author{
Beat Knusel, ${ }^{1}$ Patrick P. Michel, ${ }^{1}$ James S. Schwaber, ${ }^{2}$ and Franz Hefti ${ }^{1}$ \\ 'Andrus Gerontology Center and Department of Biological Sciences, University of Southern California, Los Angeles, \\ California 90089, and ${ }^{2}$ Neurobiology Group, DuPont de Nemours \& Co., Wilmington, Delaware 19898
}

\begin{abstract}
To study the selectivity of neurotrophic actions in the brain, we analyzed the actions of several known growth factors on septal cholinergic, pontine cholinergic, and mesencephalic dopaminergic neurons in culture. Similar to nerve growth factor (NGF), basic fibroblast growth factor (bFGF) stimulated choline acetyltransferase activity in septal cultures. In contrast to NGF, bFGF also enhanced dopamine uptake in mesencephalic cultures and stimulated cell proliferation in all 3 culture types. Insulin and the insulin-like growth factors I and II stimulated transmitter-specific differentiation and cell proliferation in all culture types. Epidermal growth factor (EGF) produced a small increase in dopamine uptake by mesencephalic cells and stimulated cell proliferation in all culture types. In septal cultures, bFGF was most effective when given at early culture times, NGF at later times. The stimulatory actions of bFGF and insulin did not require the presence of glial cells and were not mediated by NGF. In mesencephallc cultures, the stimulation of dopamine uptake by bFGF and EGF was dependent on glial proliferation. The results suggest different degrees of selectivity of the neurotrophic molecules. NGF and, very similarly, bFGF seem to influence septal cholinergic neurons directly and rather selectively, whereas the neurotrophic actions of insulin and the insulin-like growth factors appear to be more general.
\end{abstract}

It is widely believed that for a given neuron or neural connection to survive during development, proper contact with the projection area has to be established. The known biology of nerve growth factor (NGF) supports the concept that such neurontarget interactions are based on the production and release of specific trophic molecules by the target area which are required by the innervating neurons (for review, see Thoenen and Edgar, 1985; Purves, 1986; Thoenen et al., 1987; Barde, 1989). Besides NGF, several other substances or factors have been character-

\footnotetext{
Received May 22, 1989; revised Aug. 2, 1989; accepted Aug. 29, 1989.

Nerve growth factor was kindly provided by Dr. W. C. Mobley, San Francisco. Monoclonal antibodies against bFGF were a gift from Dr. T. Reilly, DuPont de Nemours, Wilmington, DE. This study was supported by NIH Grant NS22933 and NSF Grant BNS-8708049 and a grant from the National Parkinson Foundation, Miami.

Correspondence should be addressed to Dr. Franz Hefti, Andrus Gerontology Center, University Park, MC-0191, University of Southern California, Los Angeles, CA 90089
}

Copyright (C) 1990 Society for Neuroscience $0270-6474 / 90 / 100558-13 \$ 02.00 / 0$ ized that are able to support survival or differentiation of neurons. Ciliary neurotrophic factors (CNTF) have been isolated from chick eye (Barbin et al., 1984), rat sciatic nerve (Manthorpe et al., 1986), and bovine heart (Watters and Hendry, 1987), based on their ability to provide survival of chick embryonic ciliary ganglion cells in culture. A brain-derived neurotrophic factor (BDNF) has been purified from pig brain (Barde et al., 1982) and promotes survival and fiber outgrowth of embryonic chick sensory neurons and rat retinal cells (Davies et al., 1986; Johnson et al., 1986; Barde et al., 1987; Kalcheim et al., 1987; Hofer and Bardc, 1988). Furthcrmore, substances that were previously known for their effects on non-neuronal tissues have recently been recognized to display neurotrophic effects when tested in cell culture assays. Among these molecules are basic fibroblast growth factor (bFGF), insulin, the insulin-like growth factors I and II (IGF-I, IGF-II), and epidermal growth factor (EGF). bFGF has been shown to promote survival and fiber outgrowth of dissociated mouse and rat fetal neurons (Morrison et al., 1986; Walicke et al., 1986; Unsicker et al., 1987; Walicke, 1988 ) and to stimulate neurite formation in PC1 2 cells (Togari et al., 1985; Rydel and Greene, 1987). According to a recent report, bFGF also stimulates the proliferation of neuronal precursor cells in culture (Gensburger et al., 1987). In support of a possible function of $\mathrm{bFGF}$ in the CNS, bFGF activity and immunoreactivity and receptor for $b F G F$ have been found in the brain (Logan and Logan, 1986; Imamura et al., 1988; Presta et al., 1988).

A neuronal bFGF receptor with properties distinct from the mesenchymal receptor has recently been characterized (Walicke et al., 1989). Suggestive of many different roles of this molecule in the mammalian organism is the fact that as many as 15 previously characterized growth factors are probably similar or identical to bFGF (Gospodarowicz et al., 1986). Insulin, IGFI, and IGF-II have only recently been suggested to possess physiological functions for the CNS (for review, see Baskin et al., 1988). Receptors for insulin and the IGFs are found in the rat brain and seem to be heterogeneously distributed (Hill et al., 1986; Mendelsohn, 1987; Bohannon et al., 1988). Evidence that insulin occurs in the brain is still equivocal (Baskin et al., 1988), but mRNAs for IGF-I and IGF-II were detected in many brain areas and seem to be differentially regulated during development (Rotwein et al., 1988). In cultures of brain cells insulin, IGF-I, and IGF-II promote neuronal survival, neurite extension, expression of neuronal enzymes, and, in astrocytes but possibly also in neurons, DNA synthesis (Bhat, 1983; Lenoir and Ho- 
negger, 1983; Mill et al., 1985; Recio-Pinto et al., 1986; Aizenman and DeVellis, 1987; Kyriakis et al., 1987; Avola et al., 1988; DiCicco-Bloom and Black, 1988). Mild increases in dopamine uptake of ventral mesencephalic cultures by IGF-I and IGF-II have been reported recently (Valdes et al., 1988). EGF is primarily known as a potent mitogen for several cell types including astrocytes (Schlesinger et al., 1983; Avola et al., 1988) but, similar to bFGF, has recently been shown to promote neuronal survival and neurite outgrowth of dissociated neonatal rat brain cells in serum-free medium (Morrison et al., 1987, 1988). The EGF molecule is structurally and functionally related to transforming growth factor alpha (Anzano et al., 1982; Marquardt et al., 1984), which is synthesized in the brain (Wilcox and Derynck, 1988). Both molecules act on the same receptors (Massague, 1983). Some of the non-neuronal actions of EGF are shared by platelet-derived growth factor (PDGF; Cooper et al., 1982) and PDGF has recently been shown to play a role in glial differentiation (Noble et al., 1988; Raff et al., 1988; Richardson et al., 1988).

The concept of NGF as an instrument of target-controlled neuronal survival has been established in the PNS. The exact role of NGF in the CNS remains to be fully elucidated. Presently, actions of NGF on the cholinergic neurons of the basal forebrain and the corpus striatum are well characterized (for reviews, see Thoenen et al., 1987; Whittemore and Seiger, 1987; Hefti et al., 1989), and distribution and developmental changes of NGF and its receptor in the CNS have been extensively investigated (for recent studies, see Ayer-LeLievre et al., 1988; Buck et al., 1988; Ernfors et al., 1988; Hefti and Mash, 1988; Kiss et al., 1988; Schatteman et al., 1988; Yan and Johnson, 1988). All data are compatible with the view that NGF serves as a target-derived survival factor for basal forebrain neurons. However, it is still not known whether there is neural cell death during the development of the basal forebrain or striatal cholinergic system and whether the availability of NGF regulates the number of cholinergic neurons. Furthermore, the selectivity of the action of NGF in the CNS remains one of the principal unresolved questions. While the distribution of NGF and its receptor suggests actions of NGF on neurons other than cholinergic (Buck et al., 1988; Ernfors et al., 1988; Schatteman et al., 1988; Yan and Johnson, 1988; Large et al., 1989), no other NGF-responsive central populations have yet been identified with certainty. Far less is known about the other neurotrophic factors and their functions in the CNS. Hence, at the present time it seems equally likely that, in the CNS, neuronal survival upon proper contact with the target area is regulated by a large number of different, population-specific neurotrophic factors, or alternatively, that there is only a small number of neurotrophic factors, which may be precisely regulated during development.

In an attempt to clarify the degree of selectivity of the actions of various neurotrophic substances, we used previously established cell culture models of fetal rat septum, pons, and ventral mesencephalon (Hartikka and Hefti, 1988a, b; Knusel and Hefti, 1988; Michel et al., 1989). Septal cholinergic cells in culture respond to NGF in various ways, among them by increasing the activity of the enzyme choline acetyltransferase (ChAT; Hefti et al., 1985; Hartikka and Hefti, 1988a, b; Hatanaka et al., 1988). Pontine cholinergic neurons, located in the pedunculopontine and dorsolateral tegmental nuclei, share some of the morphological characteristics of basal forebrain cholinergic neurons and have medium- to large-sized cell bodies and long centrally ascending axons (Woolf and Butcher, 1986; Rye et al.,
1987; Goldsmith and van der Kooy, 1988). However, this cell group has been shown not to respond to NGF in vitro (Knusel and Hefti, 1988) and to lack receptors for NGF (Woolf et al., 1989). Cultures of the ventral mesencephalon were used to test for effects of trophic factors on dopaminergic cells of the substantia nigra. We have previously reported that CNTF does not seem to promote the differentiation of septal or pontine cholinergic neurons (Knusel and Hefti, 1988). In the present study trophic effects on septal and pontine cholinergic and mesencephalic dopaminergic neurons were examined for $\mathrm{bFGF}$, insulin, IGF-I, IGF-II, EGF, and NGF. Further experiments were aimed at defining differences and similarities in the actions of NGF, bFGF, and insulin on septal cholinergic cells.

\section{Materials and Methods}

Preparation of the cultures. Rat fetuses of the embryonic age E15-E17 were collected into PBS from anesthetized (Nembutal, $0.6 \mathrm{ml} / \mathrm{animal})$ mothers. The brains of the embryos were removed in L-15 medium without serum, and septal, mesencephalic, and pontine areas were dissected using previously published procedures (Hartikka and Hefti, 1988a; Knusel and Hefti, 1988; Michel et al., 1989). The tissue pieces were washed 2 times in medium and then mechanically dissociated by gently pipetting 20-30 times through a blue $(1 \mathrm{ml})$ sterile pipet in about $1.5-$ $2 \mathrm{ml}$ of medium. Immediately after this trituration, approximately 10 $\mathrm{ml}$ of medium was added and the undispersed tissue pieces were allowed to settle during the 10-20 min. Most of the supernatant, which contained the individual cells, was then transferred to a second tube. About 1.5 $\mathrm{ml}$ medium was left in the tube for a second trituration. Virtually all of the tissue was dispersed after the second trituration. The cells were spun down in a centrifuge at $200 \times \mathrm{g}(10 \mathrm{~min})$, resuspended in $5 \mathrm{ml}$ of L-15 medium, and counted in a hemocytometer using exclusion of trypan blue as criterion for viability. Aliquots of $0.6-0.8$ million viable cells were pipetted into wells of $16 \mathrm{~mm}$ diameter in 24 -well plates (Costar) which contained $0.5 \mathrm{ml}$ of growth medium (see below). Culture wells were previously coated overnight with a solution of $1 \mathrm{mg} / \mathrm{ml}$ polyethylenimine in $0.15 \mathrm{M}$ sodium borate buffer, $\mathrm{pH}$ 8.3. The wells were washed 2-3 times with sterile PBS before medium was added.

The neurons were grown in Leibovitz's L-15 medium (purchased from Gibco) with the following additions: $5 \%$ horse serum, $0.5 \%$ fetal bovine serum, and per liter of medium $2.5 \mathrm{gm} \mathrm{NaHCO}_{3}, 9.0 \mathrm{gm}$ glucose, 875 mg glutamine, $5 \mathrm{mg}$ beta-alanine, $15 \mathrm{mg}$ aspartic acid, $15 \mathrm{mg}$ cystine, $15 \mathrm{mg}$ glutamic acid, $5 \mathrm{mg}$ para-aminobenzoic acid, $50 \mathrm{mg}$ ascorbic acid, $10 \mathrm{mg}$ choline chloride, $25 \mathrm{mg}$ fumaric acid, $2.5 \mathrm{mg}$ glutathione, $60 \mathrm{mg}$ imidiazole, $10 \mathrm{mg}$ myo-inositol, $0.5 \mathrm{mg}$ alpha-lipoic acid, $2 \mathrm{mg}$ vitamin $B_{12}$ and 100,00 units penicillin $G$ and $100 \mathrm{mg}$ streptomycin. Cells were incubated at $37^{\circ} \mathrm{C}$ in a $95 \%$ air $/ 5 \% \mathrm{CO}_{2}$ humidified atmosphere. The medium was changed at approximately $3 \mathrm{hr}$ and $24 \mathrm{hr}$ after plating and, subsequently, every $2-3 \mathrm{~d}$. Each change included 2 rinses of the cells with medium. Growth factors were added after each medium change as specified in the Results. The cells were taken for biochemical determination of ChAT activity or dopamine uptake after 6-8 d in vitro, for ChAT immunocytochemistry after 10-14 d.

ChAT and neurofilament immunocytochemistry. Cultures wcrc washcd 3 times with PBS, fixed for $30 \mathrm{~min}$ in fresh $4 \%$ paraformaldehyde in PBS at room temperature, and then incubated for $3-5 \mathrm{~d}$ at $4^{\circ} \mathrm{C}$ with a monoclonal antibody against ChAT (gift of Dr. F. Eckenstein, Oregon Health Science University) or against neurofilament (RT97, Wood and Anderton, 1981; a gift from Dr. J. Wood, Wellcome Research Laboratories, Beckenham, England). The antibody was contained in $0.1 \mathrm{M}$ sodium phosphate buffer, $\mathrm{pH} 7.4$, with $5 \%$ sucrose, $5 \%$ bovine serum albumin, and $0.1 \%$ Triton X-100 (PS- solution) and normal rabbit serum (1:100 dilution). Subsequent incubations at room temperature were with biotinylated anti-rat antibody $(10 \mu \mathrm{g} / \mathrm{ml}$ PS, Vector Laboratories, Burlingame, CA) and then with an avidin-biotin conjugate of peroxidase (Vectastain), each for $2 \mathrm{hr}$. The peroxidase was visualized with diaminobenzidine and hydrogen peroxide.

Determination of ChAT activity and protein content. Culturcs werc washed with PBS and then homogenized by sonication in $250 \mu \mathrm{l}$ of 50 mм Tris- $\mathrm{HCl}$ buffer, $\mathrm{pH} 6.0$, with $0.3 \%$ Triton $\mathrm{X}-100$. Aliquots $(30-50$ $\mu$ ) of the homogenate were taken for the determination of ChAT activity according to the method of Fonnum $(1975) \cdot\left[1-{ }^{14} \mathrm{C}\right]$ acetyl-coenzyme A (NEN) was diluted with unlabeled acetyl-CoA to give a final substrate 

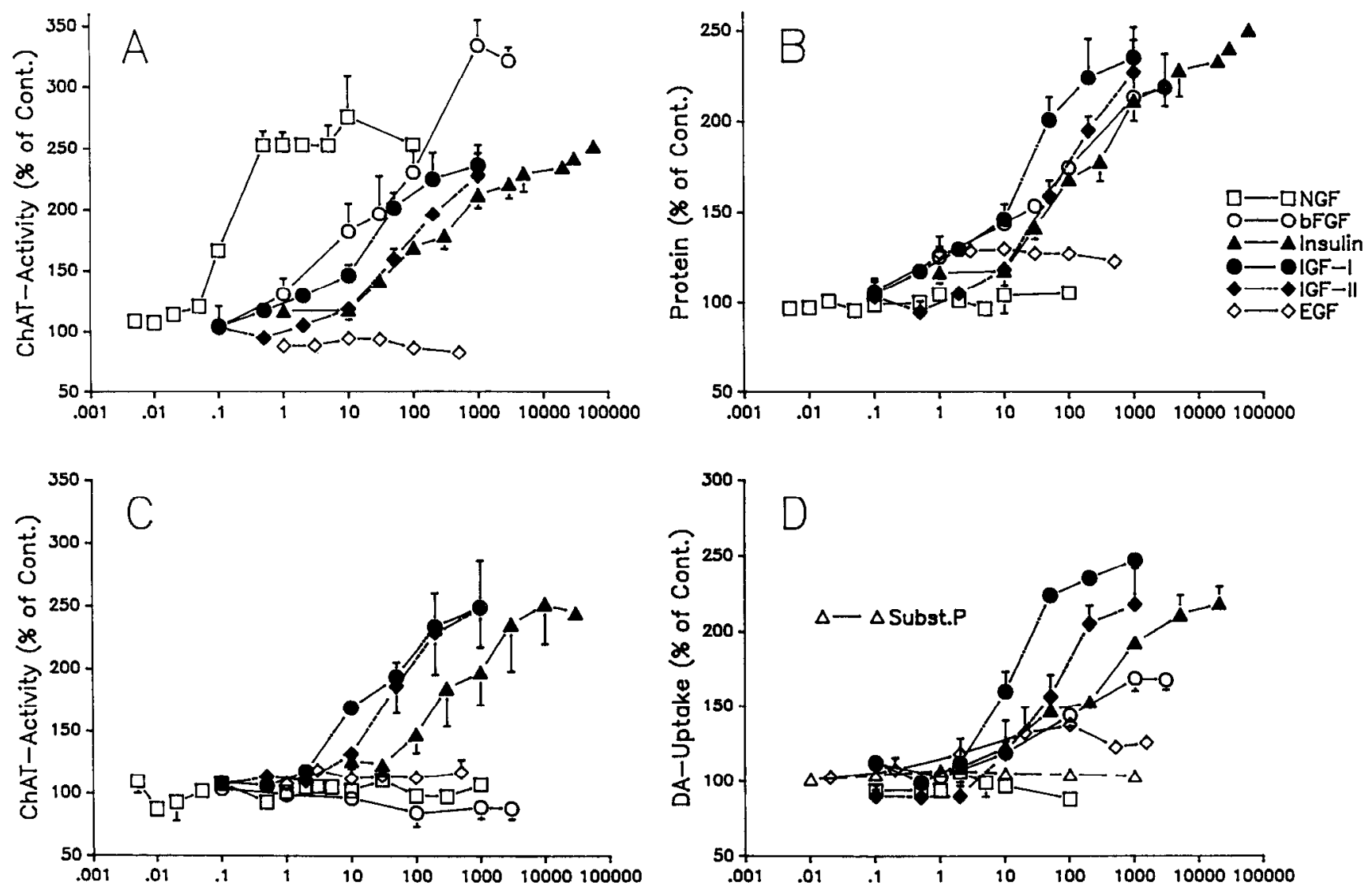

ng Growth Factor / ml Medium

Figure 1. Dose-response curves for effects of growth factors on rat brain cultures. Cultures of dissociated fetal rat brain cells (E16/E17) were grown for 1 week in the presence of growth factors as indicated in the graphs. Plating density was $0.8 \times 10^{6} / 16-\mathrm{mm}$ well. For each factor data were pooled from 2 or 3 experiments. Each symbol represents the mean of 4-8 individual cultures. Bars represent SEM; they were omitted where they would have appeared smaller than the symbol. Note order of potency in all 4 graphs: IGF-I $>$ IGF-II $>$ insulin. $A$, ChAT activity per well in septal cultures. Note high potency of NGF, but absence of effect in $B, C$, and $D$. $B$, Protein content per well in septal cultures. $C$, ChAT activity per well in cultures of pons. $D$, Dopamine uptake per well in cultures of ventral mesencephalon. Note limited effects of bFGF and EGF and absence of effect of substance $P$.

concentration of $20 \mu \mathrm{M}$ (specific activity $4.09 \mathrm{Ci} / \mathrm{mol}$ of acetyl-CoA). Incubation was at $37^{\circ} \mathrm{C}$ for $20 \mathrm{~min}$. Protein content of the cultures was measured according to the method of Bradford (1976) using bovine gamma-globulin (Bio-Rad) as a standard.

Dopamine uptake. The method used was a modification of that described by Prochiantz et al. (1981). Cells were washed twice with incubation solution (5 mM glucose, $1 \mathrm{~mm}$ ascorbic acid in PBS) and then preincubated for $5 \mathrm{~min}$ at $37^{\circ} \mathrm{C}$ with $250 \mu$ lincubation solution containing $1 \mathrm{~mm}$ pargyline. $\left[{ }^{3} \mathrm{H}\right]$ dopamine $(37 \mathrm{Ci} / \mathrm{mmol})$ was then added to give a final concentration of $50 \mathrm{~nm}$ and the cultures were incubated at $37^{\circ} \mathrm{C}$ for $15 \mathrm{~min}$. Blanks were obtained by incubating cells at $0^{\circ} \mathrm{C}$. The uptake was stopped by removing the incubation mixture, immediately followed by 5 washes with cold PBS. The cells were then lysed in $1 \%$ Triton X-100 with $10 \%$ perchloric acid and transferred to scintillation vials for counting.

Materials. Chemicals of analytical grade were purchased from Sigma, if not otherwise stated. Media and sera for tissue cultures were obtained from Gibco. Mouse NGF was purified according to Suda et al. (1978). A polyclonal sheep anti-NGF serum (Suda et al., 1978) was used, $1 \mu \mathrm{l} /$ $\mathrm{ml}$ of which inhibited the biological activity of up to $2 \mu \mathrm{g} / \mathrm{ml}$ of NGF. Bovine insulin and mouse submaxillary gland EGF were purchased from Sigma. Human recombinant bFGF was provided by Synergen (Boulder, $\mathrm{CO}$ ). This molecule was shown to stimulate proliferation of various cells at concentrations of $1-10 \mathrm{ng} / \mathrm{ml}$. bFGF was stored at $2 \mathrm{mg} / \mathrm{ml}$ in 10 $\mathrm{mM}$ sodium phosphate buffer, $\mathrm{pH} 7.0$, containing $0.3 \mathrm{~m}$ glycerol and $0.3 \mathrm{mg} / \mathrm{ml}$ heparin. This stock solution was kept at $-70^{\circ} \mathrm{C}$ and further dilutions were prepared immediately before addition to the cultures.
Human recombinant IGF-I and IGF-II were obtained from Eli Lilly I aboratories (Indianapolis, IN). Stock solutions of $1 \mathrm{mg} / \mathrm{ml}$ were kept. at $-70^{\circ} \mathrm{C}$ and further diluted in growth medium.

\section{Results}

Trophic actions on septal cholinergic neurons

In septal cultures, the activity of the cholinergic marker enzyme, ChAT, was elevated by bFGF, insulin, IGF-I, and IGF-II in a similar way as earlier shown for NGF. The dose-response relationship was established for each of the compounds (Fig. 1A). NGF was most potent in stimulating ChAT activity, producing a half-maximal response at a concentration of $0.16 \mathrm{ng} / \mathrm{ml} \mathrm{me-}$ dium $(6.0 \mathrm{pM})$, whereas these concentrations were $88.8 \mathrm{ng} / \mathrm{ml}$ (5.4 $\mathrm{nM}$ ) for bFGF, $255.0 \mathrm{ng} / \mathrm{ml}(42.5 \mathrm{nM})$ for insulin, $24.4 \mathrm{ng} /$ $\mathrm{ml}(3.19 \mathrm{nM})$ for IGF-I, and $76.4 \mathrm{ng} / \mathrm{ml}(10.2 \mathrm{nM})$ for IGF-II as determined from the pooled data of 2-3 experiments per growth factor (Fig. 1A). When measured $7 \mathrm{~d}$ after plating, the various factors were approximately equally effective in producing elevation of ChAT activity, but concentrations of approximately $1 \mathrm{ng} / \mathrm{ml} \mathrm{NGF}$ (38 pM), $1 \mu \mathrm{g} / \mathrm{ml}$ IGF-I or IGF-II (130 nM) or bFGF (60 nM), or $5 \mu \mathrm{g} / \mathrm{ml}$ insulin ( $800 \mathrm{nM}$ ) had to be used to produce maximal responses. EGF at concentrations between 1 

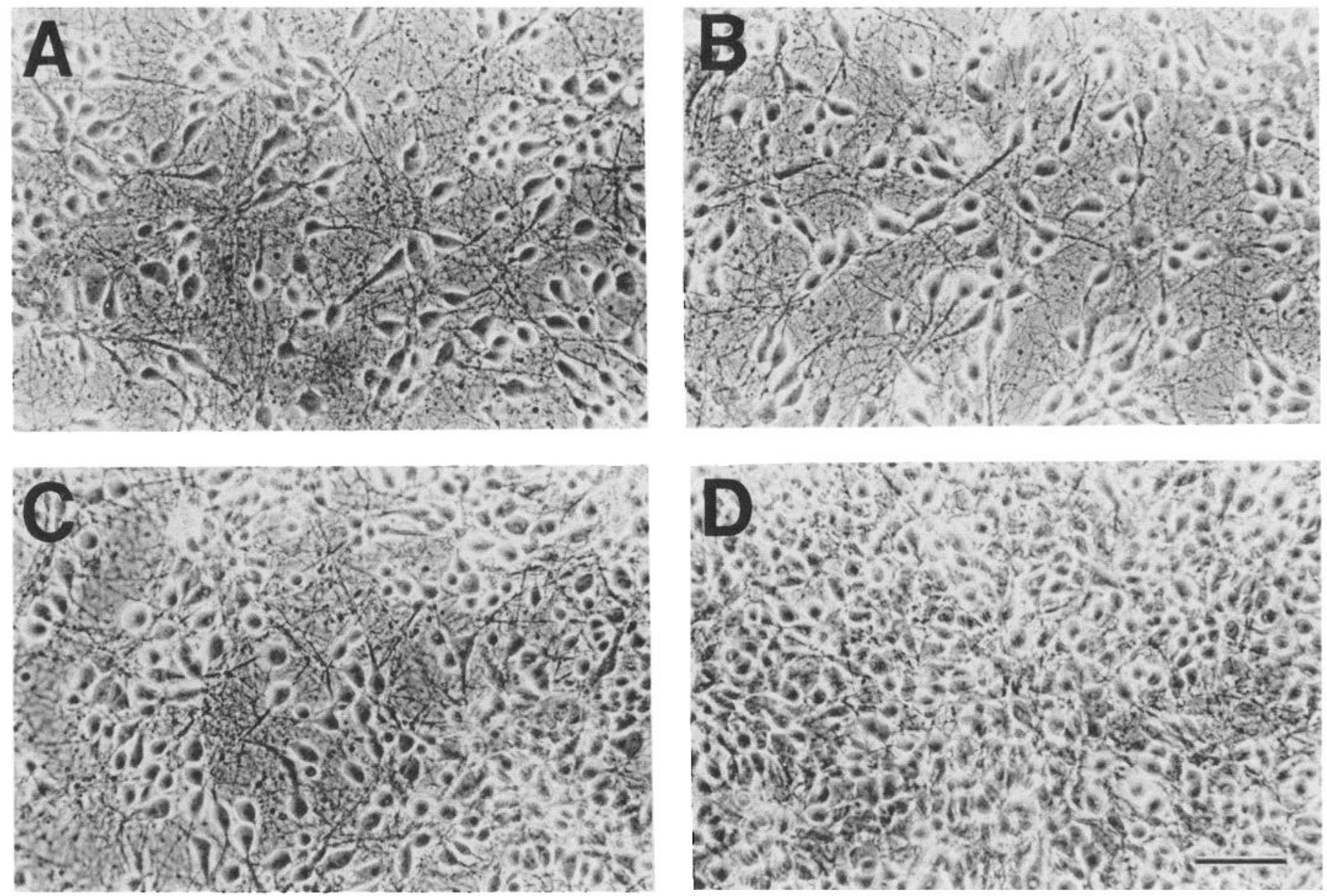

Figure 2. Phase-contrast micrographs of living septal cultures grown in presence of NGF, insulin, or bFGF. Cells were grown for $7 \mathrm{~d}$ without growth factors $(A)$, in the presence of $50 \mathrm{ng} / \mathrm{ml} \mathrm{NGF}(B), 30 \mu \mathrm{g} / \mathrm{ml}$ insulin $(C)$, or $1 \mu \mathrm{g} / \mathrm{ml}$ bFGF $(D)$. Plating density was $0.8 \times 10^{6}$ cells $/$ well. Control cultures and cultures grown with NGF appear identical whereas the presence of insulin or bFGF substantially increased cell density. Scale bar, $50 \mu \mathrm{m}$

and $500 \mathrm{ng} / \mathrm{ml}(0.17$ and $82 \mathrm{nM})$ failed to increase ChAT activity in septal cultures (Fig. 1A). Similarly, no effects were observed with PDGF, which was tested between 0.6 and $15 \mathrm{ng} / \mathrm{ml}$ (data not shown).

\section{Trophic actions on pontine cholinergic neurons and mesencephalic dopaminergic neurons}

As shown previously (Knusel and Hefti, 1988) and in marked contrast to the situation in septal cultures, NGF in concentrations up to $1000 \mathrm{ng} / \mathrm{ml}$ did not enhance ChAT activity in pontine cultures (Fig. 1C). NGF also failed to elevate dopamine uptake in mesencephalic cultures (Fig. 1D). In contrast, insulin, IGFI, and IGF-II markedly increased transmitter-specific differentiation in both systems. ChAT activity in pontine cultures and dopamine uptake in mesencephalic cultures were elevated by $100-200 \%$ above control levels (Fig. 1, C, D). Effective concentrations of the 3 factors in pontine and mesencephalic cultures were similar to those observed in septal cultures. $\mathrm{ED}_{50} \mathrm{~s}$ were calculated in pontine cultures at $386.4 \mathrm{ng} / \mathrm{ml}$ for insulin $(64.4$ $\mathrm{nM}), 21.8 \mathrm{ng} / \mathrm{ml}$ for IGF-I $(2.8 \mathrm{nM})$, and $42.6 \mathrm{ng} / \mathrm{ml}$ for IGF-II $(5.7 \mathrm{nM})$ and in mesencephalic cultures at $311.5 \mathrm{ng} / \mathrm{ml}$ for insulin $(51.9 \mathrm{nM}), 13.9 \mathrm{ng} / \mathrm{ml}$ for IGF-I $(1.8 \mathrm{nM})$, and $47.5 \mathrm{ng} / \mathrm{ml}$ for IGF-II (6.4 nM). The rank order of potency, therefore, in all 3 culture systems was IGF-I > IGF-II > insulin. bFGF, in con- centrations between 10 and $3000 \mathrm{ng} / \mathrm{ml}$, did not enhance ChAT activity in pontine cultures but elevated dopamine uptake in mesencephalic cultures, although to a smaller degree than the insulin family of growth factors (Fig. 1, C, D). As in septal cultures, EGF at concentrations between 1 and $500 \mathrm{ng} / \mathrm{ml}$ failed to increase ChAT activity in pedunculopontine cultures (Fig. 1C). In mesencephalic cultures these concentrations resulted in a modest maximal increase of dopamine uptake of $38 \%$ above control levels (Fig. 1D). Half-maximal response in mesencephalic cultures was achieved with $61.8 \mathrm{ng} / \mathrm{ml}$ bFGF (3.7 nM) and $1.0 \mathrm{ng} / \mathrm{ml} \mathrm{EGF}(0.16 \mathrm{~nm})$. Substance $P$ was recently reported to elevate the activity of tyrosine hydroxylase in cultures of substantia nigra cells (Friedman et al., 1988). Addition of 0.1 ng to $10 \mu \mathrm{g} / \mathrm{ml}$ (74 pM and $7.4 \mu \mathrm{M}$ ) of substance P did not influence dopamine uptake in our mesencephalic cultures (Fig. $1 D)$.

\section{Mitogenic effects}

bFGF, which is a potent mitogen for various cell populations, stimulated cell proliferation in our cultures. Three to $4 \mathrm{~d}$ after plating, the density of cells was clearly higher than in control cultures, and usually after $5 \mathrm{~d}$ in vitro, the cultures were confluent. After about 1 week in vitro cultures treated with bFGF showed a very high rate of metabolism requiring daily change 

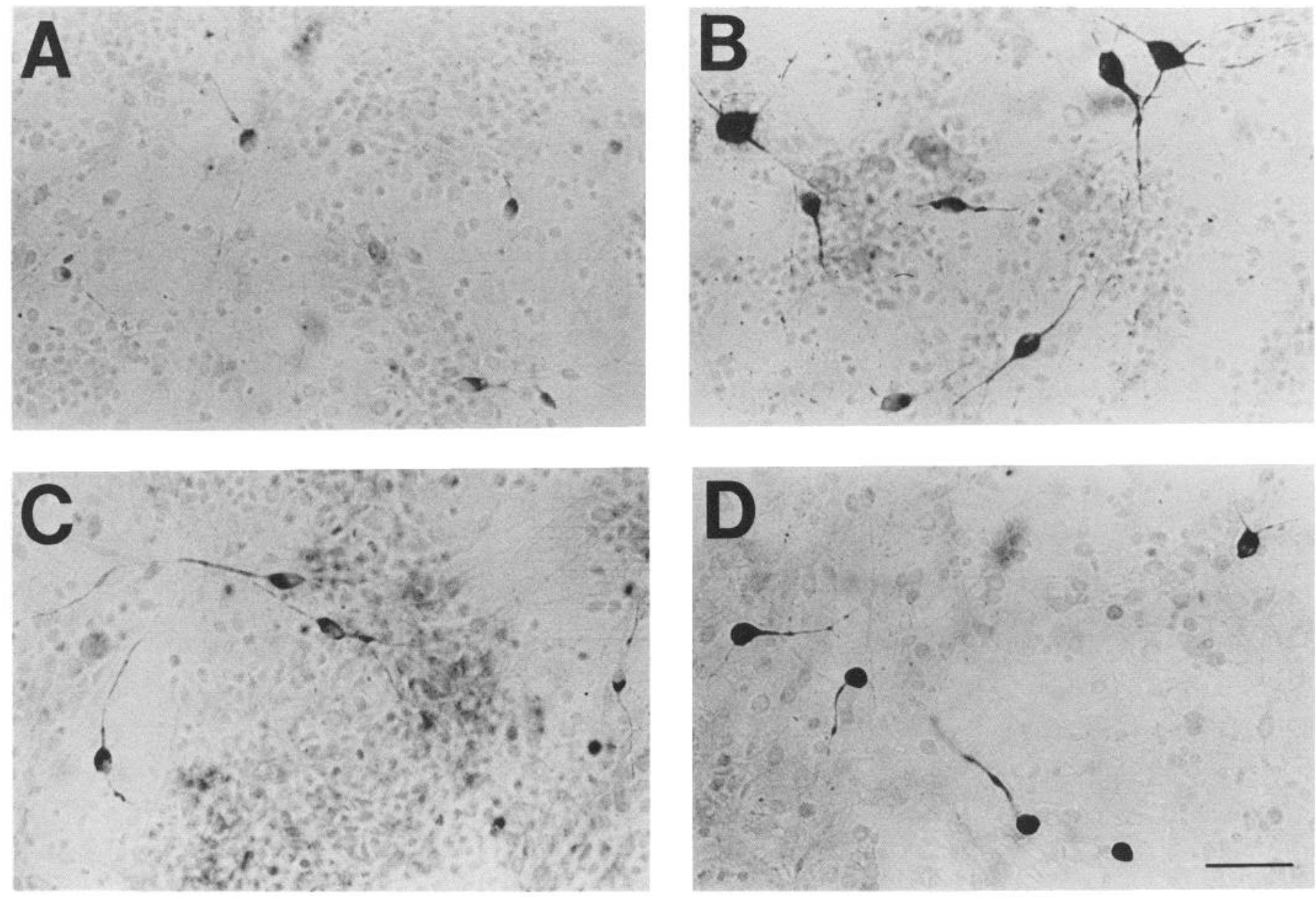

Figure 3. Bright-field micrographs of septal cultures immunostained with a monoclonal antibody against ChAT. Cultures were grown for $10 \mathrm{~d}$. Plating density and culture conditions were the same as those of the cultures shown in Figure 2 . $A$, No growth factors; $B, 50 \mathrm{ng} / \mathrm{ml}$ NGF; $C, 30$ $\mu \mathrm{g} / \mathrm{ml}$ insulin; $D, 1 \mu \mathrm{g} / \mathrm{ml}$ bFGF. Note the weak staining intensity in $A$, intermediate intensity in $C$, and strong staining in $B$ and $D$. Cell bodies in bFGF-treated cultures $(D)$ appear smaller than those treated with NGF $(B)$. Scale bar, $50 \mu \mathrm{m}$.

of medium to avoid acidification. At this time, bFGF-treated cultures were densely packed and their appearance in phasecontrast microscopy was clearly different from that of control or NGF-treated cultures (Fig. 2). In agreement with the visual observations, bFGF produced a dose-dependent increase in protein mass in all 3 culture systems used. This finding for septal cultures is shown in Figure $1 B$. The presence of insulin, IGF-I, or IGF-II resulted in cell proliferation and a similar maximal

\begin{tabular}{lcl}
\hline Table 1. Effects of insulin, IGF-I, and IGF-II on septal cultures \\
Growth factors & $\begin{array}{l}\text { ChAT/well } \\
(\mathrm{pmol} / \mathrm{min})\end{array}$ & $\begin{array}{l}\text { Protein/well } \\
(\mu \mathrm{g})\end{array}$ \\
\hline CONT & $82.6 \pm 2.9$ & $146.2 \pm 3.6$ \\
IGF-I & $167.6 \pm 4.1$ & $282.7 \pm 10.9$ \\
IGF-II & $153.0 \pm 9.1$ & $251.8 \pm 5.4$ \\
Insulin & $149.0 \pm 3.0$ & $253.1 \pm 2.9$ \\
IGF-I + IGF-II & $163.3 \pm 6.4$ & $278.9 \pm 6.0$ \\
IGF-I + Insulin & $153.1 \pm 7.0$ & $264.0 \pm 7.6$ \\
IGF-II + Insulin & $159.3 \pm 8.3$ & $258.0 \pm 13.5$
\end{tabular}

Cultures were prepared and grown like those shown in Figure 2; concentrations: IGF-I and IGF-II, $1 \mu \mathrm{g} / \mathrm{ml}$; insulin, $30 \mu \mathrm{g} / \mathrm{ml}$. Values are means \pm SEM; $n=4$ 8. All differences with control are statistically significant $(p<0.001$; Student's $t$-test). protein increase as bFGF (Figs. $1 B, 2 C$ ). The cultures, however, as judged from the acidification of the medium, did not develop the same high rate of metabolism. EGF increased protein content at concentrations from 1 to $500 \mathrm{ng} / \mathrm{ml}$, but the increase in protein content was less than was attained with $\mathrm{bFGF}$, insulin, or the insulin-like growth factors. NGF, as shown previously (Hartikka and Hefti, 1988a; Knusel and Hefti, 1988), did not influence the protein content in septal, pontine, or mesencephalic cells. Similarly, PDGF failed to elevate the protein content of septal cultures (data not shown). Growth factors that stimulated both transmitter specific differentiation and cellular proliferation always showed similar concentration requirements for these effects (Fig. 1, $A, B$ ).

\section{Further characterization of action of $b F G F$ and insulin on septal cholinergic neurons}

The actions of IGF-I, IGF-II, and insulin on septal cultures were not additive. Combining maximally effective concentrations of these substances did not elevate ChAT activity or protein content above the level attained by either of the 3 factors alone (Table 1). Given these findings, further studies were limited to insulin, which served as a representative for this family of growth factors.

Biochemical determination of ChAT activity of neuronal cul- 

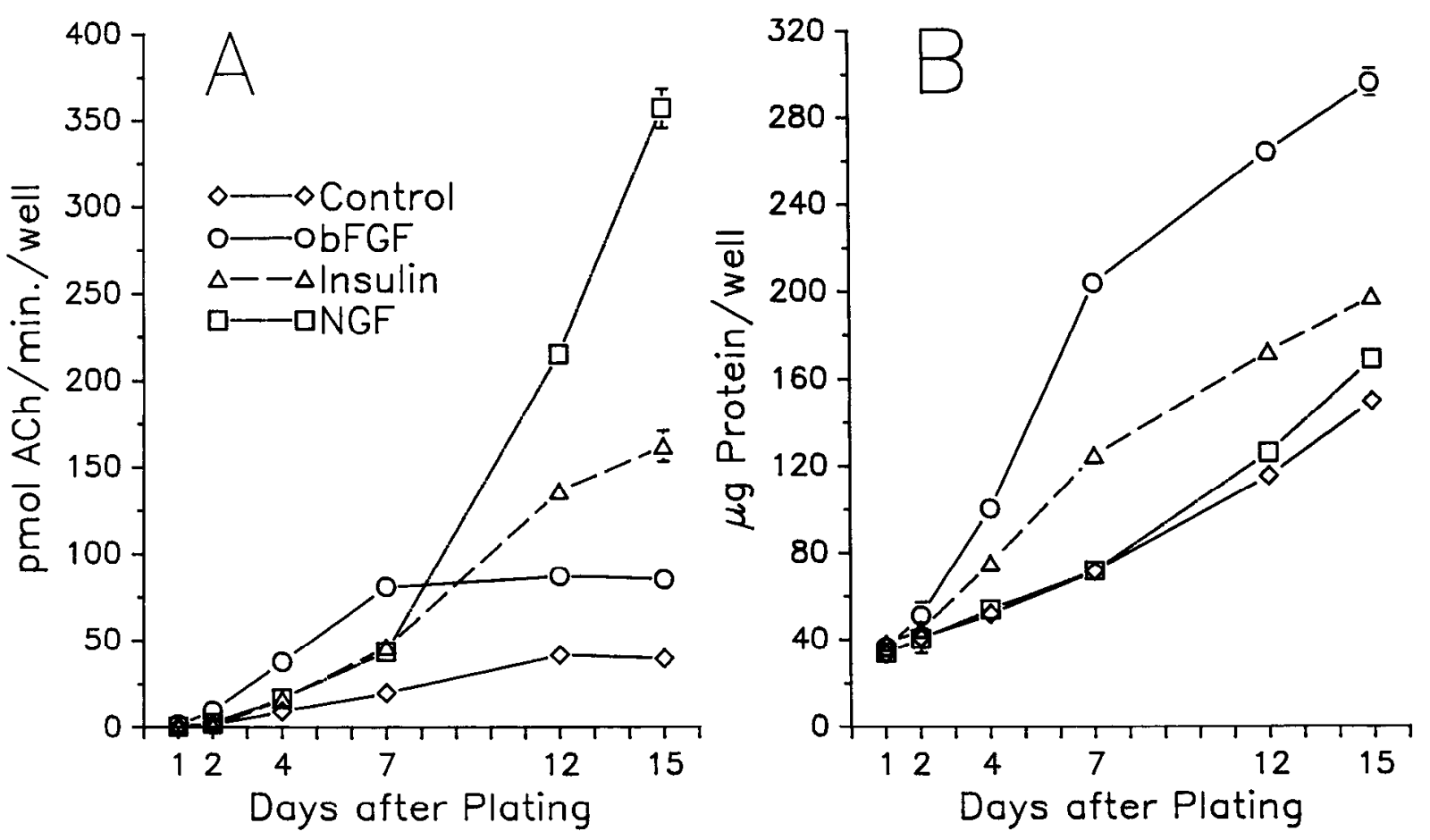

Figure 4. Time course of action of NGF, bFGF, and insulin on ChAT activity and protein content in septal cultures. At day $0,0.6 \times 10^{6}$ fetal (E16) rat septal cells were plated per $16-\mathrm{mm}$ well. Growth factors were added immediately after plating and with every medium change. Four cultures per treatment group were taken for ChAT and protein assays at the indicated times. The rate of increase of ChAT activity was initially highest in bFGF-treated cultures but higher final levels werc reached with insulin or NGF treatment.

tures does not discriminate between increased survival of cholinergic cells and increased expression of the enzyme in individual cells. To tentatively assess the presence of the enzyme in individual cells, septal control cultures and cultures treated with NGF, insulin, or bFGF were stained immunocylochemically for ChAT. As shown earlier (Hartikka and Hefti, 1988a; Knusel and Hefti, 1988), only a small number of weakly stained ChAT-positive neurons was visible in control cultures (Fig. $3 A$ ), whereas in NGF-treated septal cultures, ChAT staining revealed many darkly stained, large bipolar and multipolar cells with branched processes (Fig. $3 B$ ). Similarly, addition of bFGF and insulin to the medium elevated staining intensity of ChATpositive neurons. The staining intensity in bFGF-treated cultures was comparablc to that in NGF-treated cultures but the cell bodies seemed to be smaller and to carry fewer branched processes (Fig. $3 D$ ). Slightly lower staining intensities were typical of cultures grown in presence of insulin but the appearance of the neurons was similar to that in NGF-treated cultures (Fig. $3 B$ ), except for their smaller cell bodies. Treatment with either of the 3 factors increased staining intensity of maximally ChATpositive neurons above the maximal staining observed in control cultures. Although immunocytochemical staining intensity might not directly reflect the concentration of antigen, these observations suggest that NGF, bFGF, and insulin elevate ChAT expression in individual cholinergic neurons. Further evidence that $\mathrm{bFGF}$ most likely increases ChAT activity in individual neurons was provided by an experiment that employed different plating densities (data not shown). bFGF was equally effective in low density ( 0.2 Mio. cells/16-mm well) as in high-density cultures (0.8-3.2 Mio cells/16-mm well), where survival of cholinergic neurons is maximal and cannot be further increased by NGF (Hartikka and Hefti, 1988a).
Despite the similarities of the effects of bFGF, insulin, and NGF on cultured septal cholinergic neurons, there were pronounced differences among these factors with regard to the time course of their action on ChAT activity (Fig. 4). During the first week in vitro ChAT activity was highest in bFGF-treated cultures (Fig. $4 A$ ). After $7 \mathrm{~d}$ bFGF produced no further increase in ChAT activity but continued to stimulate proliferation of nonneuronal cells as reflected by a continuous rise of the protein content (Fig. 4B). In contrast, the most pronounced increase of ChAT activity in NGF-treated cultures was observed after more than $7 \mathrm{~d}$ in culture. Similarly, in the presence of insulin the ChAT increase was more pronounced after $7 \mathrm{~d}$ in vitro but, in contrast to NGF-treated cultures, started to level off after approximately $12 \mathrm{~d}$ in vitro. Final levels of ChAT activity which were measured after $15 \mathrm{~d}$ in vitro were $909 \%$ of control in NGFtreated cultures, $413 \%$ in cultures treated with insulin, and $216 \%$ in cultures treated with bFGF.

To test whether septal cholinergic neurons are more responsive to bFGF early in vitro, or if the lower final level of ChAT activity in bFGF-treated cultures in Figure 4 simply reflects an inability of our culture conditions to support the cxcessive growth of these cultures, the 3 factors were applied at different times after plating (Fig. 5). Each set of cultures was grown in the presence of the factors for $3 \mathrm{~d}$ and then taken for ChAT assay. When the factors were given immediately after plating, ChAT activity was increased to $327 \%$ of control by bFGF, to $184 \%$ by NGF, and to $125 \%$ by insulin. If the factors were added after the cultures had been grown for $8 \mathrm{~d}$ under control conditions, the relative effects were $110 \%$ for bFGF, $266 \%$ for NGF, and $131 \%$ for insulin. This result confirms a pronounced effect of bFGF at early culture times. At late times bFGF is less effective, whereas for NGF an inverse relationship holds true. In contrast, 

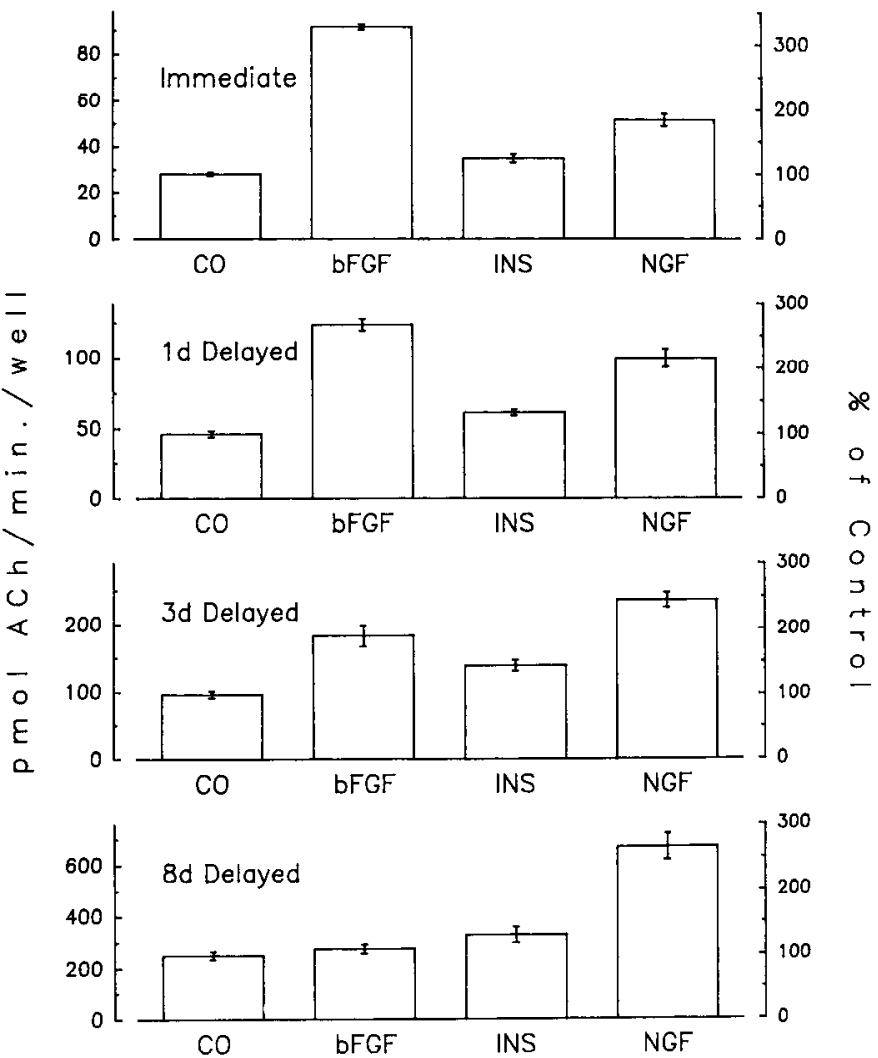

Figure 5. Change of responsiveness of septal cultures to NGF, bFGF, and insulin during culture time. Growth factors were added to cultures of fetal rat septal cells at different times after plating. The cultures were then grown for 3 additional days in the presence of the factors and taken for the measurement at the end of this 3-d treatment period. Note the high ChAT increase induced by bFGF at early and by NGF at late in vitro times. bFGF: $1 \mu \mathrm{g} / \mathrm{ml}$ bFGF; INS: $30 \mu \mathrm{g} / \mathrm{ml}$ insulin; NGF: $50 \mathrm{ng} /$ ml NGF.

insulin increases ChAT activity about equally at all times. The low response to bFGF after $8 \mathrm{~d}$ and to insulin does not reflect a principal inability of the cultures to respond. If the cultures were grown in presence of growth factors for $6 \mathrm{~d}$ instead of 3 after a delay of $8 \mathrm{~d}$, bFGF increased ChAT activity to $166 \%$, insulin to $165 \%$, and NGF to $574 \%$ of control levels (data not shown). The large effect of bFGF on ChAT activity at initial culture times could reflect enhanced survival of freshly dissociated neurons during the first days in culture, as shown for various neuronal populations in serum-free medium (Morrison et al., 1986; Walicke et al., 1986; Walicke, 1988), or increased mitosis of neuronal precursors (Gensburger et al., 1987). We therefore counted the total number of neurons present in our

Table 2. bFGF, insulin, and NGF do not enhance cell survival during initial 48-hr period in vitro

\begin{tabular}{ll} 
Growth factors & Surviving cells \\
\hline Control & $386,643 \pm 19,014$ \\
bFGF $(1 \mu \mathrm{g} / \mathrm{ml})$ & $405,215 \pm 18,468$ \\
Insulin $(30 \mu \mathrm{g} / \mathrm{ml})$ & $406,143 \pm 9959$ \\
NGF $(50 \mathrm{ng} / \mathrm{ml})$ & $396,805 \pm 11,726$
\end{tabular}

Cultures prepared like those shown in Figure 2 were fixed after $2 \mathrm{~d}$ in vitro and taken for immunocytochemical visualization of neurofilament proteins. Means \pm SEM; $n=12$ cultures after $2 \mathrm{~d}$ in vitro and compared the results with determinations of ChAT activity in cultures of the same age. Neurons were identified using neurofilament immunocytochemistry. Cultures treated with bFGF did not contain significantly more neurons than NGF- or insulin-treated cultures or untreated controls after $2 \mathrm{~d}$ in vitro (Table 2), whereas ChAT activity was elevated to $335 \%$ of control with bFGF, $151 \%$ of control with NGF, and $120 \%$ of control with insulin treatment (Table 3). These findings suggest that the early bFGF-mediated elevation of ChAT activity is not due to a general promotion of neuronal survival or stimulation of neuroblast mitosis in our cultures. They do not rule out the possibility of a selective enhancement of the survival of cholinergic neurons.

Since bFGF and insulin strongly promoted the growth of nonneuronal cells and may affect other neuronal populations besides the cholinergic cells in our septal cultures, their stimulatory actions on these neurons could be indirect and secondary to an action on receptors located on other cells. In particular, in septal cultures bFGF or insulin could stimulate production and release of NGF. Anti-NGF antibodies, at a sufficient concentration to completely block the NGF-mediated increase of ChAT activity, failed to abolish the bFGF- or insulin-mediated elevations (Fig. 6). This experiment does not completely rule out the possibility that the antibodies failed to penetrate to the sites of synthesis and action of endogenously produced NGF. However, the effects of maximally effective concentrations of bFGF, insulin, and NGF on ChAT activity and protein content were additive (Table 4), suggesting that NGF, bFGF, and insulin each stimulate different cellular mechanisms.

To test whether the effects of bFGF and insulin on cultured cholinergic neurons were mediated by glial cells, cell proliferation was inhibited by the addition of cytosine arabinoside (ara$\mathrm{C}, 1.8 \mu \mathrm{M}$ ) to the medium (Table 5). We have earlier shown that adding ara- $\mathrm{C}$ to our septal cultures reduces the number of astrocytes to less than $5 \%$ of the number counted in control cultures without affecting the number of neurons (Hartikka and Hefti, 1988a). In confirmation of our earlier results, NGF was found to elevate ChAT activity in septal cultures in presence or absence of glial cells. Similarly, bFGF produced similar relative increases in ChAT activity in septal cultures, and insulin in septal, pontine, and mesencephalic cultures with or without ara$C$, suggesting that the action of neither factor in these cultures depends on the presence of glial cells. In contrast, in mesencephalic cultures, the stimulatory action of bFGF and EGF on dopamine uptake was abolished by the presence of ara- $\mathrm{C}$ in the medium.

$\begin{aligned} & \text { Table 3. bFGF but not insulin or NGF produces a profound } \\
& \text { elevation of ChAT activity in septal cultures during the initial 48-hr } \\
& \text { period in vitro }\end{aligned}$
\begin{tabular}{lc} 
Growth factors & ChAT/well $(\mathrm{pmol} / \mathrm{min})$ \\
\hline Control & $9.9 \pm 0.7$ \\
bFGF $(1 \mu \mathrm{g} / \mathrm{ml})$ & $33.2 \pm 1.8^{a}$ \\
Insulin $(30 \mu \mathrm{g} / \mathrm{ml})$ & $11.9 \pm 0.7$ \\
$\mathrm{NGF}(50 \mathrm{ng} / \mathrm{ml})$ & $15.0 \pm 0.5^{b}$
\end{tabular}

Cultures were grown like those shown in Figure 2 but taken for analysis after only $2 \mathrm{~d}$ in vitro. Values given are Ineans $\pm \mathrm{SEM} ; n=6$.

a Higher than control value and value of NGF group, $p<0.001$.

${ }^{b}$ Higher than control value, $p<0.002$ (Student's $t$-test). 


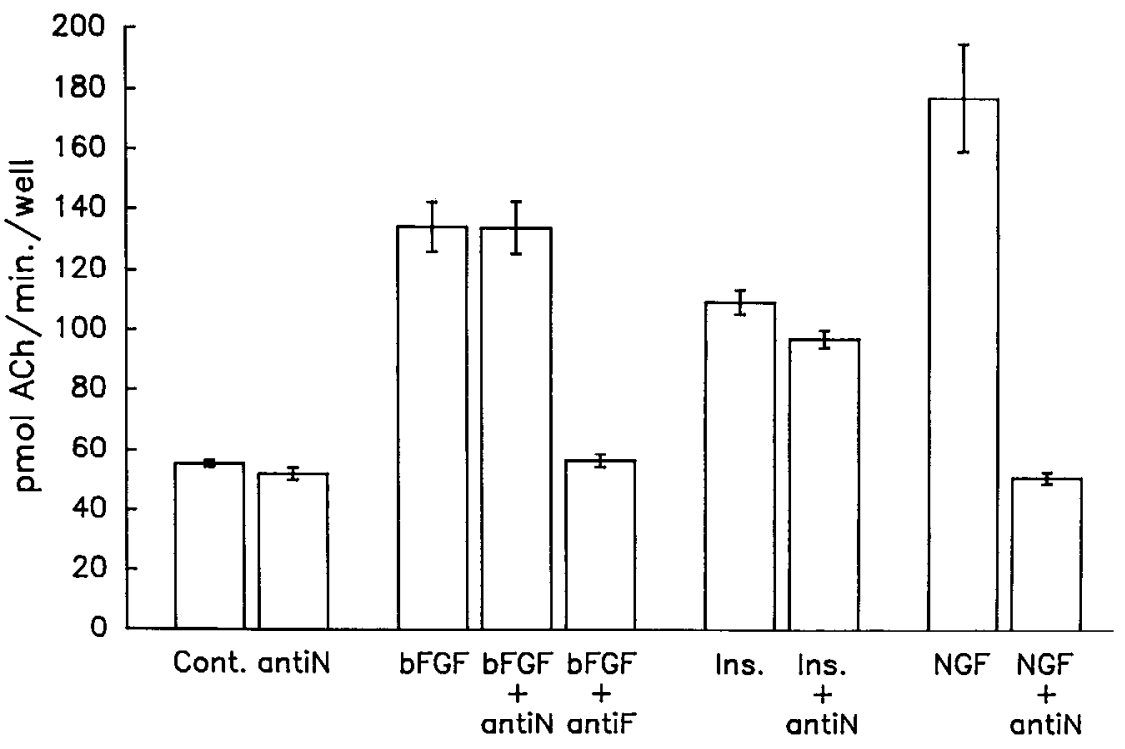

Figure 6. NGF- and bFGF-specific immunological blockage of ChAT increase in septal cultures. Cultures were grown as for Figures 2 and 3. The NGFmediated ChAT increase, but not the bFGF- or insulin-mediated increase, was completcly blocked by antiscrum against NGF. Monoclonal antibodies against bFGF prevented the bFGF-mediated ChAT increase.

\section{Discussion}

It is well established that developmental growth and differentiation of septal forebrain cholinergic neurons is stimulated by NGF (Honegger and Lenoir, 1982; Gnahn et al., 1983; Hefti et al., 1985; Hatanaka and Tsukui, 1986; Mobley et al., 1986; Johnston et al., 1987; Martinez et al., 1987; Hartikka and Hefti, 1988a). The present study suggests that bFGF, insulin, and the insulin-like growth factors, but not EGF, exert similar actions. The actions of NGF, bFGF, and insulin on septal cholinergic neurons were additive and appear to be mediated by different mechanisms, whereas insulin, IGF-I, and IGF-II probably act via the same receptors. Development of pontine cholinergic neurons in vitro was stimulated by insulin and IGFs, but not by NGF, bFGF, or EGF. In vitro development of mesencephalic dopaminergic neurons was stimulated by insulin, IGFs, and, to a smaller degree, by bFGF and EGF. In all 3 culture systems, proliferation of non-neuronal cells was increased by insulin, IGFs, bFGF, and EGF, but not NGF.

$\mathrm{bFGF}$, which was originally purified from brain and pituitary based on its mitogenic activity for Balb/c $3 T 3$ cells (Gospoda-

\begin{tabular}{|c|c|c|}
\hline Growth factors & $\begin{array}{l}\text { ChAT/well } \\
\text { (pmol/min) }\end{array}$ & $\begin{array}{l}\text { Protein/well } \\
(\mu \mathrm{g})\end{array}$ \\
\hline CONT & $20.2 \pm 0.3$ & $76.2 \pm 4.9$ \\
\hline bFGF & $65.0 \mp 4.1$ & $212.6 \pm 15.1$ \\
\hline Insulin & $47.1 \pm 8.6$ & $162.6 \pm 22.0$ \\
\hline $\mathrm{NGF}$ & $43.3 \pm 7.4$ & $70.6 \pm 3.7$ \\
\hline $\mathrm{NGF}+\mathrm{bFGF}$ & $85.6 \pm 12.0^{\alpha}$ & $194.9 \pm 25.8$ \\
\hline NGF + insulin & $97.9 \pm 6 . .5^{a}$ & $149.0 \pm 7.4$ \\
\hline $\mathrm{bFGF}+$ insulin & $83.5 \pm 3.1^{a}$ & $348.7 \pm 8.2^{a}$ \\
\hline $\mathrm{NGF}+\mathrm{bFGF}+$ insulin & $117.6 \pm 2.2^{a, b}$ & $348.1 \pm 12.2^{a}$ \\
\hline
\end{tabular}

Cultures were grown for $6 \mathrm{~d}$. Means $\pm \mathrm{SEM} ; n=4$; concentrations factors: NGF, $50 \mathrm{ng} / \mathrm{ml} ; \mathrm{bFGF}, 1 \mu \mathrm{g} / \mathrm{ml}$; insulin, $30 \mu \mathrm{g} / \mathrm{ml}$. Values of all treated groups are higher than those of control group, $p<0.01$.

a Higher than value obtained in culture grown with one of the growth factors only, $p<0.05$.

"Higher than group treated with bFGF and insulin, $p<0.05$. rowicz et al., 1978), is a potent mitogen for many cells (see Gospodarowicz, 1984). Recently, this molecule has been shown in vitro to support survival and neurite outgrowth of neurons from various brain regions (Morrison et al., 1986; Walicke et al., 1986; Unsicker et al., 1987; Hatten et al., 1988; Walicke, 1988 ) and to promote neuronal differentiation of PC12 cells (Rydel and Greene, 1987; Schubert et al., 1987). Intracerebral administration of bFGF prevents degenerative changes of lesioned cholinergic neurons of the basal forebrain (Anderson et al., 1988; Otto et al., 1989). Although bFGF stimulates proliferation and influences the morphology of astrocytes in culture (Kniss and Burry, 1988; Perraud et al., 1988), its actions on neurons are believed not to be mediated by glial cells (Morrison et al., 1986; Walicke and Baird, 1988). Several observations make it seem likely that the effects of bFGF on the cholinergic neurons in our septal cultures resulted from a direct action of this molecule on the cholinergic cells. First, bFGF was most effective at very early culture times (1-2 d in vitro) when cellcell contact is still minimal. Second, preventing proliferation of

Table 5. Preventing cell proliferation abolishes effects of bFGF and EGF in mesencephalic cultures but does not prevent the action of bFGF and NGF in septal cultures and of insulin in all culture types

\begin{tabular}{clcc} 
& & No Ara-C & Ara-C $(1.8 \mu \mathrm{M})$ \\
\hline Septal cultures & Control & $114.4 \pm 7.5$ & $82.1 \pm 7.3$ \\
(pmol ACh/min/well) & bFGF & $251.3 \pm 26.4^{b}$ & $217.4 \pm 17.7^{c}$ \\
& Insulin & $180.9 \pm 20.4^{a}$ & $120.4 \pm 12.9^{a}$ \\
& NGF & $370.0 \pm 28.6^{c}$ & $179.1 \pm 18.1^{b}$ \\
Pontine cultures & Control & $17.2 \pm 0.2^{b}$ & $20.1 \pm 1.3$ \\
(pmol ACh/min/well) & bFGF & $14.7 \pm 0.5^{b}$ & $19.9 \pm 0.7$ \\
& Insulin & $32.6 \pm 2.2^{c}$ & $35.8 \pm 1.9^{c}$ \\
Mesencephalic cultures & Control & $55.3 \pm 2.3$ & $57.5 \pm 2.7$ \\
(fmol DA/min/well) & bFGF & $86.4 \pm 5.9^{b}$ & $60.7 \pm 4.2$ \\
& Insulin & $106.3 \pm 8.3^{b}$ & $92.2 \pm 5.7^{b}$ \\
& EGF & $70.0 \pm 5.0^{a}$ & $58.6 \pm 3.3$
\end{tabular}

Cultures were grown for $8 \mathrm{~d}$. Means \pm SEM; $n=4-6$; concentrations of factors as in Table 4; a.b., significantly higher than corresponding control.

" $p<0.05$.

${ }^{5} p<0.01$

${ }^{c} p<0.001$ (Student's $t$-test). 
cells by adding ara-C did not diminish the actions of bFGF. Third, transfer of medium from cultures grown in presence of bFGF did not reveal any "conditioning" effect of bFGF (data not shown). The bFGF-mediated elevation in ChAT activity, at least at early times in vitro when this effect is particularly pronounced, does not reflect a general effect of bFGF on survival of dissociated neurons in culture as could be expected from the above-mentioned data (Morrison et al., 1986; Walicke et al., 1986) or, alternatively, a general proliferation of neuronal precursors (Gensburger et al., 1987). Under our culture conditions, bFGF did not increase the total number of cells in septal cultures up to $2 \mathrm{~d}$ after plating. However, we cannot exclude the possibility that bFGF could have selectively promoted the survival of cholinergic neurons.

The concentrations of bFGF required to stimulate cholinergic differentiation in our septal cultures were higher than those found to promote survival and neurite outgrowth of freshly plated neurons. Reported concentrations producing $50 \%$ of maximal neuron survival range from $15 \mathrm{pg} / \mathrm{ml}$ to $1 \mathrm{ng} / \mathrm{ml}$ (Morrison et al., 1986; Walicke et al., 1986; Unsicker et al., 1987; Walicke, 1988). Concentrations of bFGF stimulating half-maximal proliferation of various non-neuronal cells have been found to be approximately $50 \mathrm{pg} / \mathrm{ml}$ (Esch et al., 1985; Ferrara et al., 1988). Walicke et al. (1989) recently characterized a neuronal bFGF receptor with an affinity 10 times lower than that of mesenchymal bFGF receptors, suggesting that neuronal cells respond to higher concentrations of $\mathrm{bFGF}$. We observed some variation among dose-response curves for bFGF in our experiments with septal cultures. The lowest concentration that was half-maximally active in any of the experiments was $21.4 \mathrm{ng} / \mathrm{ml}$. Since determination of bFGF by radioimmunoassay in our solutions revealed a loss of about half of the bFGF during routine handling of the substance (data not shown), the actual minimal concentration of bFGF in the medium producing a half-maximal response probably was approximately $10 \mathrm{ng} / \mathrm{ml}$. Still, the exact reason for the higher dose requirements in our cultures remains to be determined. Possibly, at least part of the difference might be due to differences in plating densities of the cells. We plated $3-5 \times 10^{5} / \mathrm{cm}^{2}$ in our experiments whereas only $16 \times 10^{3} / \mathrm{cm}^{2}$ cells were plated in neuronal survival experiments (Walicke et al., 1986). Under our culture conditions the potency of bFGF seemed to be negatively correlated with plating density. It has indeed been shown for a nontransformed cell line that the number of surface bFGF receptors decreases with increasing cell density (Veomett et al., 1989). It also seems possible that the added bFGF is more rapidly removed from the medium at higher cell density by specific and nonspecific binding or other mechanisms and that the effective concentration of bFGF in the medium may decline very quickly.

Insulin, IGF-I, and IGF-II promoted transmitter-specific development in all 3 culture systems to a similar cxtent. Maximal concentrations of the 3 factors, when applied to septal cultures, were equally effective in increasing ChAT activity and combinations of the factors did not result in additive effects, suggesting that insulin, IGF-I, and IGF-II acted via the same receptors. The rank order of potency in all 3 systems, IGF-I > IGF-II > insulin, is in accordance with the relative affinities of the factors for a recently characterized neuronal IGF-I receptor (Burgess et al., 1987). Insulin, IGF-I, and IGF-II, and their mRNA and receptors have been reported to occur and to be heterogeneously distributed in the adult mammalian brain (Dorn et al., 1982; Sara et al., 1982; Hill et al., 1986; Mendelsohn, 1987; Bohannon et al., 1988; Rotwein et al., 1988). None of the areas used for our cell cultures or the target regions of the neuronal populations studied have been recognized as being rich in insulin or IGF receptors in the above-mentioned studies. Thus, it seems surprising that insulin, IGF-I, and IGF-II act similarly and profoundly on cholinergic neurons of the septal and pontine areas as well as on the dopaminergic neurons of the substantia nigra in culture. However, it has been shown that the expression of insulin and IGFs and of their receptors is developmentally regulated in a complex and pronounced way with generally high levels of mRNA and receptors for the IGFs (Bassas et al., 1985; Pomerance et al., 1988; Rotwein et al., 1988). The regional distributions of receptors for insulin and IGFs or mRNAs coding for receptor proteins in the embryonic brain are not known. It is conceivable that insulin and, in particular, the IGFs play a different, and more widespread role during early neuronal development than in the adult brain. This concept is supported by findings that insulin and IGFs can support neuronal survival and induce neurite formation and the synthesis of neural proteins in developing neurons (Bothwell, 1982; Bhat, 1983; Puro and Agardh, 1984; Recio-Pinto et al., 1986; Aizenman and DeVellis, 1987; Kyriakis et al., 1987, DiCicco-Bloom and Black, 1988).

Insulin and the IGFs are known to stimulate the synthesis of glial proteins in fetal rat brain cell cultures (Lenoir and Honegger, 1983), DNA, RNA, proteins in astroglial cell cultures (Avola et al., 1988), and lipids in oligodendrocyte-enriched glial cultures (Van der Pal et al., 1988). In our cultures, insulin and the IGFs increased cell density and protein content. However, treatment of the cultures with ara- $\mathrm{C}$ to prevent cellular proliferation only slightly diminished the transmitter-specific effects of insulin. It seems likely that insulin, and probably also IGF-I and IGF-II, elevated ChAT activity and dopamine uptake in our cultures by a direct action on neurons and, to a minor extent, by indirect action via stimulation of glial cell proliferation. While a direct action on cholinergic and dopaminergic neurons seems likely, our studies do not rule out the possibility that other neurons mediated these effects. Any indirect stimulations mediated by glial cells or neuronal cells do not involve NGF or bFGF, since, in septal cultures, the effect of insulin was additive to the action of either of the other factors and since antibodies against NGF failed to block the insulin effect.

Many recent studies on neurotrophic actions have been based on the concept of target-derived survival factors, as suggested by the well-known biology of NGF (for reviews, see Thoenen and Edgar, 1985; Purves, 1986; Thoenen et al., 1987; Barde, 1989). This concept does not exclude that a multitude of different factors are required at specific ontogenetic stages for a neuron to develop properly and to maintain its structural integrity and function during adult life. Different roles for bFGF, insulin, IGFs, and NGF in neural development are suggested by the observed time courses of their stimulatory action on ChAT activity in septal cultures. During the first $7 \mathrm{~d}$ in vitro, bFGF induced a significantly larger increase of ChAT activity than insulin or NGF. In the cultures with insulin, ChAT activity rose up to day 15 but the rate of increase declined after $12 \mathrm{~d}$ in vitro, whereas in cultures with NGF the most dramatic increase in ChAT activity occurred after $7 \mathrm{~d}$. A second experiment in which $b F G F$, insulin, and NGF were applied at different times of the culture period confirmed a relatively higher responsiveness of the cholinergic neurons to bFGF at early and to NGF at late in vitro times (see Fig. 5). A reduced late effect of bFGF 
could be explained by the presence of endogenous bFGF in the control cultures at later culture times. Still, even maximal concentrations of $\mathrm{bFGF}$, present for $6 \mathrm{~d}$ after a delay of 1 week (data not shown) or present during an entire culture period of $15 \mathrm{~d}$ (see Fig. 4), resulted in a much lower level of ChAT activity than the presence of NGF under the same conditions.

An alternative interpretation to an intrinsic, timed modulation of responsiveness to $\mathrm{bFGF}$ is suggested by a possible role of bFGF in repair processes (Finklestein et al., 1988). The mechanical trituration of the tissue that is used to dissociate embryonic cells in the preparation of the cell cultures severs existing neurites and may also disrupt cell body membranes. During the initial culture period, stimulation of repair processes may lead to similar measurable effects as enhancement of developmental processes. It can be speculated that the relatively larger effect of bFGF during the initial culture period demonstrates an active role of this substance in healing and regeneration, whereas NGF, which exerts its most significant influence on ChAT activity during later stages, promotes differentiation of the cholinergic cells. Although attractive, this hypothesis is not supported by our finding that $\mathrm{bFGF}$ did not enhance ChAT activity in pontine cultures, where, probably because of the more advanced development, the dissociation inflicts more cell damage than in septal cells (Knusel and Hefti, 1988). Our finding that NGF, bFGF, and insulin increase the intensity of the immunocytochemical staining for ChAT suggests that the biochemically measured ChAT activity reflects elevated expression of this protein by cholinergic neurons. However, it does not rule out that $\mathrm{bFGF}$ and insulin promote survival of cholinergic neurons as earlier shown to occur with NGF under specific culture conditions (Hartikka and Hefti, 1988a). Furthermore, it cannot be excluded that the 3 growth factors may affect different subpopulations of cholinergic neurons or induce noncholinergic neurons to express cholinergic traits. Further studies will be needed to test for these possibilities.

We believe that part of the importance of the present study lies in the comparison of effects of several known trophic substances on different neuronal populations studied under identical conditions. The exact roles and importance of neurotrophic factors in CNS development are poorly understood. While there is strong evidence that NGF serves as a target-derived neurotrophic factor for cholinergic neurons of the basal forebrain and promotes their differentiation, it is still unclear whether, similar to the situation in the peripheral sympathetic system, NGF controls the developmental survival of these cells. No comparable target-derived neurotrophic factors for other central neuronal populations have been identified with certainty. It is not known whether most or all central neuronal populations depend on target-derived factors for development and survival and, if they do, whether there exists a multitude of population-specific factors or only a small number of factors with a precisc devclopmental regulation of their mechanisms. Our results confirm the relative selectivity of the action of NGF on the basal forebrain cholinergic neurons despite recent reports of a more widespread localization of NGF and NGF receptors in developing than in adult brain (Buck et al., 1988; Ernfors et al., 1988; Schatteman et al., 1988; Yan and Johnson, 1988; Large et al., 1989). bFGF, similar to NGF, strongly stimulates ChAT activity in septal cholinergic neurons. Considering the anteroposterior gradient in brain development, a developmentally short-lasting influence of bFGF on neuronal development could explain the lack of effect on pontine cholinergic, the relatively minor effect on mesencephalic dopaminergic, and the pronounced early effect on septal cholinergic cells. However, the action of bFGF on dopaminergic cells of the mesencephalic cultures, in contrast to its effect on the cholinergic neurons of the septal cultures, depends on cell proliferation. It is likely, therefore, that the effect of bFGF on the dopaminergic cells is mediated by glia cells and that its only direct effect on neurons in our cultures is on the septal cholinergic cells. The stimulatory actions of insulin and the IGFs on neural development and differentiation are most likely very widespread and, at least in vitro, not limited to a specific time in development. This family of growth factors therefore seem unlikely candidates for target-derived, neuronpopulation-specific neurotrophic factors. Nevertheless, their time- and site-specific presence could be required during development and their function during this time might be different from later, more general, stimulating influences on many biochemical parameters.

Our finding that NGF and bFGF directly influence cholinergic neurons of the basal forebrain, but not the other studied neuronal populations, invites an interpretation that seems interesting in another context than discussed so far. It can be speculated that septal cholinergic neurons have a higher intrinsic plasticity than pontine cholinergic or mesencephalic dopaminergic neurons and therefore can respond with changes in morphology and biochemistry to different trophic or specifying factors (Varon and Adler, 1980) or other treatments. This possibility seems particularly interesting, since central cholinergic mechanisms have long been recognized to be instrumental in memory processes (see Squire and Davis, 1981; Singh et al., 1985).

\section{References}

Aizenman, Y., and J. DeVellis (1987) Brain neurons devclop in a serum and glial free environment: Effects of transferrin, insulin, insulin-like growth factor-I and thyroid hormone on neuronal survival, growth and differentiation. Brain Res. 406: 32-42.

Anderson, K. J., D. Dam, S. Lee, and C. W. Cotman (1988) Basic fibroblast growth factor prevents death of lesioned cholinergic neurons in vivo. Nature 332: 360-362.

Anzano, M. A., A. B. Roberts, A. M. Chester, A. Komoriya, L. C. Lamb, J. M. Smith, and M. B. Sporn (1982) Synergistic interaction of two classes of transforming growth factors from murine sarcoma cells. Cancer Res. 42: 4776-4778.

Avola, R., D. F. Condorelli, S. Surrentino, L. Turpeenoja, A. Costa, and A. M. Giuffrida Stella (1988) Effect of epidermal growth factor, and insulin on DNA, RNA, and cytoskeletal protein labeling in primary rat astroglial cell cultures. J. Neurosci. Res. 19: 230-238.

Ayer-LeLievre, C., L. Olson, T. Ebendal, A. Seiger, and H. Persson (1988) Expression of the beta-nerve growth factor gene in hippocampal neurons. Science 240: 1339-1341.

Barbin, G., M. Manthorpe, and S. Varon (1984) Purification of the chick eye ciliary neuronotrophic factor. J. Neurochem. 43: 14681478.

Barde, Y. A. (1989) Trophic factors and neuronal survival. Neuron 2: $1525-1534$.

Barde, Y. A., D. Edgar, and H. Thoenen (1982) Purification of a new neurotrophic factor from mammalian brain. EMBO J. 1: 549-553.

Barde, Y. A., A. M. Davies, J. E. Johnson, R. M. Lindsay, and H. Thoenen (1987) Brain-derived neurotrophic factor. Prog. Brain. Res. 71: 185-189.

Baskin, D. G., B. J. Wilcox, D. P. Figlewicz, and D. M. Dorsa (1988) Insulin and insulin-like growth factors in the CNS. Trends Neurosci. 11: 107-111.

Bassas, L., F. De Pablo, M. A. Lesniak, and J. Roth (1985) Ontogeny of receptors for insulin-like peptide in chick embryo tissues: Early dominance of insulin-like growth factor over insulin receptors in brain. Endocrinology 117: 2321-2329.

Bhat, N. (1983) Insulin dependent neurite outgrowth in cultured embryonic mouse brain cells. Dev. Brain Res. 11: 315-318. 
Bohannon, N. J., E. S. Corp, B. J. Wilcox, D. P. Figlewicz, D. M. Dorsa, and D. G. Baskin (1988) Localization of binding sites for insulinlike growth factor I (IGF-I) in the rat brain by quantitative autoradiography. Brain Res. 444: 205-213.

Bothwell, M. (1982) Insulin and somatemedin MSA promote nerve growth factor-independent neurite formation by cultured chick dorsal root ganglionic sensory neurons. J. Neurosci. Res. 8: 225-231.

Bradford, M. M. (1976) A rapid and sensitive method for the quantitation of microgram quantities of protein utilizing the principle of protein-dye binding. Anal. Biochem. 72: 248-254.

Buck, C. R., H. J. Martinez, M. V. Chao, and I. Black (1988) Differential expression of the nerve growth factor receptor gene in multiple brain areas. Dev. Brain Res. 44: 259-268.

Burgess, S. K., S. Jacobs, P. Cuatrecasas, and N. Sahyoun (1987) Characterization of a neuronal subtype of insulin-like growth factor I receptor. J. Biol. Chem. 262: 1618-1622.

Cooper, J. A., D. F. Bowen-Pope, E. Raines, R. Ross, and T. Hunter (1982) Similar effects of platelet-derived growth factor and epidermal growth factor on the phosphorylation of tyrosine in cellular proteins. Cell 31: 263-273.

Davies, A. M., H. Thoenen, and Y. A. Barde (1986) The response of chick sensory neurons to brain-derived neurotrophic factor. J. Neurosci. 6: 1897-1904.

DiCicco-Bloom, E., and I. Black (1988) Insulin growth factors regulate the mitotic cycle in cultured rat sympathetic neuroblasts. Proc. Natl. Acad. Sci. USA 85: 4066-4070.

Dorn, A., H. G. Bernstein, A. Rinne, H. J. Hahn, and M. Ziegler (1982) Insulin-like immunoreactivity in the human brain. Histochemistry 74: 293-300.

Ernfors, P., F. Hallbook, T. Ebendal, E. M. Shooter, M. J. Radeke, T. P. Misko, and H. Persson (1988) Developmental and regional expression of $\beta$-nerve growth factor receptor mRNA in the chick and rat. Neuron 1: 983-996.

Esch, F., A. Baird, N. Ling, N. Ueno, F. Hill, L. Denoroy, R. Klepper, D. Gospodarowicz, P. Bohlen, and R. Guillemin (1985) Primary structure of bovine pituitary basic fibroblast growth factor (FGF) and comparison with the amino-terminal sequence of bovine brain acidic FGF. Proc. Natl. Acad. Sci. USA 82: 6507-6511.

Ferrara, N., F. Ousley, and D. Gospodarowicz (1988) Bovine brain astrocytes express basic fibroblast growth factor, a neurotropic and angiogenic mitogen. Brain Res. 462: 223-232.

Finklestein, S. P., P. J. Apostolides, C. G. Caday, J. Prosser, M. F Philips, and M. Klagsbrun (1988) Increased basic fibroblast growth factor (bFGF) immunoreactivity at the site of focal brain wounds. Brain Res. 460: 253-259.

Fonnum, F. (1975) A rapid radiochemical method for the determination of choline acetyltransferase. J. Neurochem. 24: 407-409.

Friedman, W. J., C. F. Dreyfus, B. McEwen, and I. B. Black (1988) Presynaptic transmitters and depolarizing influences regulate development of the substantia nigra in culture. J. Neurosci. 8: 3616-3623.

Gensburger, C., G. Labourdette, and M. Sensenbrenner (1987) Brain basic fibroblast growth factor stimulates the proliferation of rat neuronal precursor cells in vitro. FEBS Lett. 217: 1-5.

Gnahn, H., F. Hefti, R. Heumann, M. Schwab, and H. Thoenen (1983) NGF-mediated increase of choline acetyltransferase (ChAT) in the neonatal forebrain: Evidence for a physiological role of NGF in the brain? Dev. Brain Res. 9: 45-52.

Goldsmith, M., and D. van der Kooy (1988) Separate noncholinergic descending and cholinergic ascending projections from the nucleus tegmenti pedunculopontinus. Brain Res. 445: 386-391.

Gospodarowicz, D. (1984) Brain and pituitary fibroblast growth factors. In Hormonal Proteins and Peptides, Vol. XII, C. H. Li, ed., pp. 205-230, Academic, New York.

Gospodarowicz, D., H. Bialecki, and G. Greenburg (1978) Purification of the fibroblast growth factor activity from bovine brain. J. Biol Chem. 253: 3736-3743.

Gospodarowicz, D., G. Neufeld, and L. Schweigerer (1986) Molecular and biological characterization of fibroblast growth factor, an angiogenic factor which also controls the proliferation and differentiation of mesoderm and neuroectoderm derived cells. Cell Differentiation 19: 1-17.

Hartikka, J., and F. Hefti (1988a) Development of septal cholinergic neurons in culture: Plating density and glial cells modulate effects of NGF on survival, fiber growth, and expression of transmitter-specific enzymes. J. Neurosci. 8: 2967-2985.
Hartikka, J., and F. Hefti (1988b) Comparison of nerve growth factor's effects on development of septum, striatum, and nucleus basalis cholinergic neurons in vitro. J. Neurosci. Res. 21: 352-364.

Hatanaka, H., and H. Tsukui (1986) Differential effects of nerve growth factor and glioma-conditioned medium on neurons cultured from various regions of fetal rat central nervous system. Dev. Brain Res. 30: 47-56.

Hatanaka, H., H. Tsukui, and I. Nihonmatsu (1988) Developmental change in the nerve growth factor action from induction of choline acetyltransferase to promotion of cell survival in cultured basal forebrain cholinergic neurons from postnatal rats. Dev. Brain Res. 39: 88-95.

Hatten, M. E., M. Lynch, R. E. Rydel, J. Sanchez, J. Joseph-Silverstein, D. Moscatelli, and D. Rifkin (1988) In vitro neurite extension by granule neurons is dependent upon astroglial-derived fibroblast growth factor. Dev. Biol. 125: 280-289.

Hefti, F., and D. C. Mash (1988) Localization of nerve growth factor receptors in the human brain. In Molecular Biology of the Human Brain, UCLA Symposia on Molecular and Cellular Biology, New Series, Vol. 72, E. G. Jones, ed., pp. 119-132, Liss, New York.

Hefti, F., J. Hartikka, F. Eckenstein, H. Gnahn, R. Heumann, and M. Schwab (1985) Nerve growth factor (NGF) increases choline acetyltransferase but not survival or fiber outgrowth of cultured fetal septal cholinergic neurons. Neuroscience 14: 55-68.

Hefti, F., J. Hartikka, and B. Knusel (1989) Function of neurotrophic factors in the adult and aging brain and their possible use in the treatment of neurodegenerative diseases. Neurobiol. Aging 10:515533.

Hill, J. M., M. A. Lesniak, C. B. Pert, and J. Roth (1986) Autoradiographic localization of insulin receptors in rat brain: Prominence in olfactory and limbic areas. Neuroscience 17: 1127-1138.

Hofer, M. M. and Y. A. Barde (1988) Brain-derived neurotrophic factor prevents neuronal death in vivo. Nature 331: 261-262.

Honegger, P., and D. Lenoir (1982) Nerve growth factor (NGF) stimulation of cholinergic telencephalic neurons in aggregating cell cultures. Dev. Brain Res. 3: 229-239.

Imamura, T., Y. Tokita, and Y. Mitsui (1988) Purification of basic FGF receptors from rat brain. Biochem. Biophys. Res. Commun. 155: 583-590.

Johnson, J. E., Y. A. Barde, M. Schwab, and H. Thoenen (1986) Brainderived neurotrophic factor supports the survival of cultured rat retinal ganglion cells. J. Neurosci. 6: 3031-3038.

Johnston, M. V., J. L. Rutkowski, B. H. Wainer, J. B. Long, and W. C Mobley (1987) NGF effects on developing forebrain cholinergic neurons are regionally specific. Neurochem. Res. 12: 985-994.

Kalcheim, C., Y. A. Barde, H. Thoenen, and N. M. LeDouarin (1987) In vivo effect of brain-derived neurotrophic factor on the survival of developing dorsal root ganglion cells. EMBO J. $6: 2811-2813$.

Kiss, J., J. McGovern, and A. J. Patel (1988) Immunohistochemical localization of cells containing nerve growth factor receptors in the different regions of the adult rat forebrain. Neuroscience 27: 731748 .

Kniss, D. A., and R. W. Burry (1988) Serum and fibroblast growth factor stimulate quiescent astrocytes to re-enter the cell cycle. Brain Res. 439: 281-288.

Knusel, B., and F. Hefti (1988) Nerve growth factor promotes development of rat forebrain but not pedunculopontine cholinergic neurons in vitro; lack of effect of ciliary neuronotrophic factor and retinoic acid. J. Neurosci. Res. 21: 365-375.

Kyriakis, J. M., R. E. Hausman, and S. W. Peterson (1987) Insulin stimulates choline acetyltransferase activity in cultured embryonic chicken retina neurons. Proc. Natl. Acad. Sci. USA 84: 7463-7467.

Large, T. H., G. Weskamp, J. C. Helder, M. J. Radeke, T. P. Misko, E. M. Shooter, and L. F. Reichardt (1989) Structure and developmental expression of the nerve growth factor receptor in the chicken central nervous system. Neuron 2: 1123-1134.

Lenoir, D., and P. Honegger (1983) Insulin-like growth factor I (IGFI) stimulates DNA synthesis in fetal rat brain cell cultures. Dev. Brain Res. 7: 205-213.

Logan, A., and S. D. Logan (1986) Distribution of fibroblast growth factor in the central and peripheral nervous system of various mammals. Neurosci. Lett. 69: 162-165.

Manthorpe, M., S. D. Skaper, L. R. Williams, and S. Varon (1986) Purification of adult rat sciatic nerve ciliary neuronotrophic factor. Brain Res. 367: 282-286. 
Marquardt, H., M. W. Hunkapiller, L. E. Hood, and G. J. Todaro (1984) Rat transforming growth factor type 1: Structure and relation to epidermal growth factor. Science 223: 1079-1082.

Martinez, H. J., C. F. Dreyfuss, G. M. Jonakait, and I. B. Black (1987) Nerve growth factor selectively increases cholinergic markers but not neuropeptides in rat basal forebrain in culture. Brain Res. 412: 295301.

Massague, J. (1983) Epidermal growth factor-like transforming growth factor. II. Interaction with epidermal growth factor receptors in human placenta membranes and A431 cells. J. Biol. Chem. 258: 1361413620.

Mendelsohn, L. G. (1987) Visualization of IGF-II receptors in rat brain. In Insulin, Insulin-like Growth Factors, and Their Receptors in the Central Nervous System, M. K. Raizada, M. I. Phillips, and D. LeRoith, eds., pp. 269-275, Plenum, New York.

Michel, P. P., B. K. Dandapani, J. Sanchez-Ramos, S. Efange, B. C. Pressman, and F. Hefti (1989) Toxic effects of potential environmental neurotoxins related to 1-methyl-4-phenylpyridinium on cultured rat dopaminergic neurons. J. Pharmacol. Exp. Ther. 248: 842850.

Mill, J. F., M. V. Chao, and D. N. Ishii (1985) Insulin, insulin-like growth factor II, and nerve growth effects on tubulin mRNA levels and neurite formation. Proc. Nall. Acad. Sci. USA 82: 7126-7130.

Mobley, W. C., J. L. Rutkowski, G. I. Tennekoon, J. Gemski, K. Buchanan, and M. V. Johnston (1986) Nerve growth factor increases choline acetyltransferase activity in developing basal forebrain neurons. Mol. Brain Res. 1: 53-62.

Morrison, R. S., A. Sharma, J. DeVellis, and R. A. Bradshaw (1986) Basic fibroblast growth factor supports the survival of cerebral cortical neurons in primary culture. Proc. Natl. Acad. Sci. USA 83: $7537-$ 7541 .

Morrison, R. S., H. I. Kornblum, F. M. Leslie, and R. A. Bradshaw (1987) Trophic stimulation of cultured neurons from neonatal rat brain by epidermal growth factor. Science 238: 72-75.

Morrison, R. S., R. F. Keating, and J. R. Moskal (1988) Basic fibroblast growth factor and epidermal growth factor exert differential trophic effects on CNS neurons. J. Neurosci. Res. 21: 71-79.

Noble, M., K. Murray, P. Stroobant, M. D. Waterfield, and P. Riddle (1988). Platelet-derived growth factor promotes division and motility and inhibits premature differentiation of the oligodendrocyte/type-2 astrocyte progenitor cell. Nature 333: 560-562.

Otto, D., M. Frotscher, and K. Unsicker (1989) Basic fibroblast growth factor and nerve growth factor administered in gel foam rescue medial septal neurons after fimbria fornix transection. J. Neurosci. Res. 22: 83-91.

Perraud, F., G. Labourdette, M. Miehe, C. Loret, and M. Sensenbrenner (1988) Comparison of the morphological effects of acidic and basic fibroblast growth factors on rat astroblasts in culture. J. Neurosci. Res. 20: 1-11.

Pomerance, M., J.-M. Gavaret, C. Jacquemin, C. Matricon, D. ToruDelbauffe, and M. Pierre (1988) Insulin and insulin-like growth factor 1 receptors during postnatal development of rat brain. Dev. Brain Res. 42: 77-83.

Presta, M., M. Foiani, M. Rusnati, J. Joseph-Silverstein, J. A. M. Maier, and G. Ragnotti (1988) High molecular weight immunoreactive basic fibroblast growth factor-like proteins in rat pituitary and brain. Neurosci. Lett. 90: 308-313.

Prochiantz, A. M., C. Daguet, A. Herbert, and J. Glowinski (1981) Specific stimulation of in vitro maturation of mesencephalic dopaminergic neurons by striatal membranes. Nature 293: 570-572.

Puro, D. G., and E. Agardh (1984) Insulin-mediated regulation of neuronal maturation. Science 225: 1170-1172.

Purves, D. (1986) The trophic theory of neural connections. Trends Neurosci. 9: 486-489.

Raff, M. C., L. E. Lillien, W. D. Richardson, J. F. Burne, and M. Noble (1988) Platelet-derived growth factor from astrocytes drives the clock that times oligodendrocyte development in culture. Nature 333:562565.

Recio-Pinto, E., M. M. Rechter, and D. N. Ishii (1986) Effects of insulin, insulin-like growth factor-II and nerve growth factor on neurite formation and survival in cultured sympathetic and sensory neurons. J. Neurosci. 6: 1211-1219.

Richardson, W. D., N. Pringle, M. J. Mosley, B. Westermark, and M. Dubois-Dalcq (1988) A role for platelet-derived growth factor in normal gliogenesis in the central nervous system. Cell 53: 309-319.

Rotwein, P., S. K. Burgess, J. D. Milbrandt, and J. E. Krause (1988)
Differential expression of insulin-like growth factor genes in rat central nervous system. Proc. Natl. Acad. Sci. USA 85: 265-269.

Rydel, R. E., and L. A. Greene (1987) Acidic and basic fibroblast growth factors promote stable neurite outgrowth and neuronal differentiation in cultures of PC12 cells. J. Neurosci. 7: 3639-3653.

Ryc, D. B., C. B. Saper, H. J. Lee, and B. H. Wainer (1987) Pedunculopontine tegmental nucleus of the rat: Cytoarchitecture, cytochemistry, and some extrapyramidal connections of the mesopontine tegmentum. J. Comp. Neurol. 259: 483-528.

Sara, V. R., K. Hall, H. von Holtz, R. Humber, B. Sjogren, and L. Wetterberg (1982) Evidence for the presence of specific receptors for insulin-like growth factors 1 (IGF-1) and 2 (IGF-2) and insulin throughout the adult human brain. Neurosci. Lett. 34: 39-44.

Schatteman, G. C., L. Gibbs, A. A. Lanahan, P. Claude, and M. Bothwell (1988) Expression of NGF receptor in the developing and adult primate central nervous system. J. Neurosci. 8: 860-873.

Schlesinger, J., A. B. Schreiber, A. Levi, I. Lax, T. Libermann, and Y. Yarden (1983) Regulation of cell proliferation by epidermal growth factor. CRC Crit. Rev. Biochem. 14: 93-111.

Schubert, D., N. Ling, and A. Baird (1987) Multiple influences of a heparin-binding growth factor on neuronal development. J. Cell Biol. 104: 635-643.

Singh, M. M., D. M. Warburton, and H. Lal (1985) Central Cholinergic Mechanisms and Adaptive Dysfunctions, Plenum, New York.

Squire, L. R., and H. P. Davis (1981) The pharmacology of memory: A neurobiological perspective. Annu. Rev. Pharmacol. Toxicol. 21: 323-356.

Suda, K., Y. A. Barde, and H. Thoenen (1978) Nerve growth factor in mouse and rat serum: Correlation between bioassay and radioimmunoassay determinations. Proc. Natl. Acad. Sci. USA 75: 40424046.

Thoenen, H., and D. Edgar (1985) Neurotrophic factors. Science 229: 238-242.

Thoenen, H., C. Bandtlow, and R. Heumann (1987) The physiological function of nerve growth factor in the central nervous system: Comparison with the periphery. Rev. Physiol. Biochem. Pharmacol. 109: 145-178.

Togari, A., G. Dickens, J. Kuzuya, and G. Guroff (1985) The effect of fibroblast growth factor on PC12 cells. J. Neurosci. 5: 307-316.

Unsicker, K., H. Reichert-Preibsch, R. Schmidt, B. Pettmann, G. Labourdette, and M. Sensenbrenner (1987) Astroglial and fibroblast growth factors have neurotrophic functions for cultured peripheral and central nervous system neurons. Proc. Natl. Acad. Sci. USA 84: 5459-5463.

Valdes, H. B., D. Nonner, D. Rulli, L. Gralnik, and J. Barrett (1988) Trophic effects of striatal proteins on central dopaminergic neurons in culturc. In Progress in Parkinson Research, F. Hefti and W. J. Weiner, eds., pp. 163-171, Plenum, New York.

Van der Pal, R. H. M., J. W. Koper, L. M. G. Van Golde, and M. Lopes-Cardozo (1988) Effects of insulin and insulin-like growth factor (IGF-I) on oligodendrocyte-enriched glial cultures. J. Neurosci. Res. 19: 483-490.

Varon, S., and R. Adler (1980) Nerve growth factors and control of nerve growth. Curr. Top. Dev. Biol. 16: 207--252.

Vcomett, G., C. Kuszynski, P. Kazakoff, and A. Rizzino (1989) Cell density regulates the number of cell surface receptors for fibroblast growth factor. Biochem. Biophys. Res. Commun. 159: 694-700.

Walicke, P. A. (1988) Basic and acidic fibroblast growth factors have trophic effects on neurons from multiple CNS regions. J. Neurosci. 8: 2618-2627.

Walicke, P. A., and A. Baird (1988) Neurotrophic effects of basic and acidic fibroblast growth factors are not mediated through glial cells. Dev. Brain Res. 40:71-79.

Walicke, P., W. M. Cowan, N. Ueno, A. Baird, and R. Guillemin (1986) Fibroblast growth factor promotes survival of dissociated hippocampal neurons and enhances neurite extension. Proc. Nall. Acad. Sci. USA 83: 3012-3016.

Walicke, P. A., J.-J. Feige, and A. Baird (1989) Characterization of the neuronal receptor for basic fibroblast growth factor and comparison to receptors in mesenchymal cells. J. Biol. Chem. 264: 41204126 .

Watters, D. J., and I. A. Hendry (1987) Purification of ciliary neurotrophic factor from bovine heart. J. Neurochem. 49: 705-713.

Whittemore, S. R., and A. Seiger (1987) The expression, localization 
and functional significance of beta-nerve growth factor in the central nervous system. Brain Res. Rev. 12: 439-464.

Wilcox, J. N., and R. Derynck (1988) Localization of cells synthesizing transforming growth factor-alpha mRNA in the mouse brain. J. Neurosci. 8: 1901-1904.

Wood, J. N., and B. H. Anderton (1981) Monoclonal antibodies to mammalian neurafilaments. Biosci. Rep. 1: 263-268.

Woolf, N. J., and L. L. Butcher (1986) Cholinergic systems in the rat brain. III. Projections from the pontomesencephalic tegmentum to the thalamus, tectum, basal ganglia, and basal forebrain. Brain Res. Bull. 16: 603-637.

Woolf, N. J., E. Gould, and L. Butcher (1989) Nerve growth factor receptor is associated with cholinergic neurons of the basal forebrain but not the pontomesencephalon. Neuroscience 30:143-152.

Yan, Q., and E. M. Johnson (1988) An immunohistochemical study of the nerve growth factor receptor in developing rats. J. Neurosci. 8: 3481-3498. 